\title{
A modified S10B silicone plastination method for preparation and preservation of scaled reptile specimens
}

\author{
Okan EKİM ${ }^{1}$, R. Merih HAZIROĞLU ${ }^{1}$, Burcu INSAL ${ }^{1}$, Caner BAKICI ${ }^{1}$, R. Orkun AKGÜN $^{1}$, \\ Selçuk TUNALI ${ }^{2}$
}

\author{
${ }^{1}$ Ankara University, Faculty of Veterinary Medicine, Department of Anatomy; ${ }^{2}$ TOBB University of Economics and Technology, \\ Faculty of Medicine, Department of Anatomy, Ankara, Turkey.
}

\begin{abstract}
Summary: Preparation and long-time preservation of reptile specimens need a meticulous work. Plastination is a convenient method to create real-like and durable specimens. However, the basic steps of silicone plastination should be changed or modified depending on the anatomical or histological features of the reptile species. Various species of scaled reptiles were plastinated for this research. The aim of this study was to evaluate the silicone plastination of scaled reptiles in a detailed manner and to create a fast but convenient protocol to obtain useful plastinates. Final products have revealed that padding with the acetone resistant and quick drying polymers before the fixation step was quite effective to provide a better anatomic form and position especially in hollow structures. Proper use of polyethylene glycol may help researchers to prevent superficial drying and adhesion of excess polymers and to inhibit the mould growth during the fixation stage. It is considered that preparation of reptile specimens with this modified plastination method will be efficacious for practical teaching of reptiles.
\end{abstract}

Keywords: Anatomy, plastination, polyethylene glycol, reptile.

\section{Pullu sürüngen örneklerinin hazırlanması ve muhafazası için modifiye S10B silikon plastinasyonu metodu}

Özet: Sürüngen preparatlarının hazırlanması ve uzun süreli muhafazası faaliyetleri, titiz bir çalışma gerektirir. Plastinasyon; dayanıklı ve gerçeğe özdeş görünümlü örnekler yaratabilmek için amaca yönelik bir metottur. Fakat sürüngen türlerinin anatomik ve histolojik özelliklerine bağlı olarak; silikon plastinasyonunun temel aşamalarında değişiklik veya modifikasyonlar yapılması gerekebilir. $\mathrm{Bu}$ araştırma için çeşitli pullu sürüngen türleri plastine edildi. Bu çalışmadaki amaç; sürüngen örnekler için silikon plastinasyonu işlemini detaylı bir şekilde değerlendirmek, faydalı plastinatlar elde edebilmek adına hızlı fakat amaca yönelik bir plastinasyon protokolü geliştirebilmekti. Elde edilen son ürünler, fiksasyon işlemi öncesi örneklerde asetona dayanıklı, hızlı sertleşen polimer dolgu malzemelerinin kullanılmasının, özellikle boşluklu yapılarda daha iyi anatomik form ve pozisyonu sağlayabilmek bakımından çok etkin olduğunu ortaya çıkarmıştır. Fiksasyon süreci boyunca polietilen glikol'ün örnekler üzerinde uygun kullanımının, yüzeyel kurumayı önlemesi, küf mantarı aktivitesini baskılaması, fazla polimerin örnek yüzeyine yapışmasını önlemesi açısından araştırıcılara yardımcı olacağı düşünülmektedir. Çeşitli sürüngen örneklerinin belirtilen modifiye silikon plastinasyon metodu ile hazırlanmasının, sürüngenlerin uygulamalı öğretimi için çok faydalı olacağı öngörülmüştür.

Anahtar sözcükler: Anatomi, plastinasyon, polietilen glikol, sürüngen.

\section{Introduction}

While the reptiles were becoming popular pets for modern world $(4,18)$, diagnosis, treatment and care services for reptiles also have come to the fore in recent years. Several reptile units have been constituted private or within the veterinary schools due to this increasing demand $(17,30)$. Not only the clinical case reports, but also the research articles focused on reptiles have been significantly increased over the last decade $(2,15,18,33$, 37). Thereby, updated lectures for reptile clinics have being organized in the veterinary education establishments considering these improvements mentioned above (35). In this context, practical reptile anatomy lectures giving on the purpose of supporting reptile clinics is a basic and essential issue $(18,35)$.

Within the scope of exotic animal anatomy course, 14 hours of reptile anatomy lecture is given on the second semester of undergraduate education in our faculty. Due to the fact that the most of the scaled reptiles such as iguanas, snakes, turtles etc. are endemic species (10), continual providing of proper cadavers has been a problem for our practical anatomy courses. Besides, manufacturers are not in tendency to produce artificial models of reptiles and current ones are insufficient for an effective teaching. 
Plastination of reptiles can be a convenient alternative to create real-like, durable specimens $(12,25$, 35). The main principle of plastination is to replace tissue fluids in the specimen with a reactive polymer through an intermediary solvent such as acetone or alcohol $(12,13$, 24). The most well-known technique is silicone plastination which can be considered as the most convenient one for the preparation of organs and whole body specimens $(9,27,32)$. An ordinary low-temperature silicone plastination is subsumed under five main steps and these are briefly defined as specimen preparation, dehydration, defatting, forced impregnation and gas curing - hardening $(22,29,32)$. However, these steps can be changed or modified depending on the anatomical or histological features of the specimen $(5,20,26,34,36)$.

The class "reptilian" includes various cold-blooded species. The largest order of this class is squamata or the scaled reptiles. Dissimilarly to the rest of reptilia the skin of the scaled reptiles forms various cornifications. These scales, horns or plates cover overall surface of the skin and hereby a specialized, dry skin forms. Substantial anatomic differences especially on the digestive, respiratory, cardiovascular and urogenital systems can be observed when compared with the mammals $(10,21)$. Therefore, the anatomic preservation, especially plastination, techniques for the reptiles may indicate variations.

However, studies based on the plastination of the squamata are quite limited according to our literature search $(16,25,35)$. The aim of this study is to evaluate the silicone plastination of scaled reptiles in a detailed manner and to discuss the plastination procedures of reptiles and mammals in previous studies. It is also aimed to create a fast but convenient protocol for the silicone plastination of squamata.

\section{Materials and Methods}

A Jackson's chameleon (Trioceros jacksonii), a central bearded dragon (Pogona vitticeps), a yellowbellied puffing snake (Pseustes sulphureus), an Emerald tree boa snake (Corallus caninus), two green iguanas (Iguana iguana), two Mediterranean chameleons (Chamaeleo chamaeleon) and two Asian water monitors (Varanus salvator) were plastinated for this study. Samples had died of natural causes in a private reptile park or in the national zoo and were brought to our faculty for post-mortem examination.

Specimen preparation: After a small median incision on the ventral part of the specimens, except the snakes, an acetone resistant polyurethane filling chemical was applied to the thoracic and abdominal cavities to avoid the subsidence of hollow parts (Figure 1B and C). Meanwhile, another acetone resistant, rapid hardening silyl modified polymer was injected from the ventral part of the snakes in every $3 \mathrm{~cm}$ equidistantly and from mouth throughout the gastrointestinal tract as well (Figure 1A). After the use of padding with polyurethane and silyl modified polymer, specimens were immobilized in their natural position and morphology with various piers such as plastic or metal bands, needles, spheres and acrylic putties (Figure 2A and B).

The polyethylene glycol (PEG) 400, a viscous liquid fixation chemical, was brushed on to the outer surface of the skin to provide a simple-superficial mould protection and to avoid drying (Figure 1D). Besides, PEG 400 helped us to prevent the adhesion of excess paddings to the skin and also enhance the penetration ability of formalin solution $(6,7,14,19)$. Polyethylene glycol 400 coated cadavers were kept in $+4{ }^{\circ} \mathrm{C}$ for 6 hours for full concretion of padding. After hardening process, the excess solidified polymers were removed easily from the specimens by the help of PEG. Formalin solution (4\%) was injected to the skin and all the body cavities ventrally including cranium by using $13 \mathrm{~mm}$ injection needle. Immediately after injection, specimens were submerged into the formalin solution just for 48 hours at $+4^{\circ} \mathrm{C}$ and then rinsed in running tap water for 6 hours.

Dehydration: Specimens were pre-cooled to $+4^{\circ} \mathrm{C}$ again and then submerged in pre-cooled $99.5 \%$ acetone bath at $-25^{\circ} \mathrm{C}$. The species were put into different air-tight containers to define the alterations on the dehydration parameters of various species. The volume of the pure acetone used was 10 times that of the specimens to be dehydrated. The concentration of the acetone was monitored with an acetone meter in every 24 hours for verification of a proper and accurate dehydration. The acetone bath was immediately changed when the concentration was recorded same in two consecutive days. Dehydration process was carried on until the concentration was stabilized at $\geq 97 \%$.

Although defatting is a standard procedure for various tissues to be plastinated, this stage was skipped to avoid specimens' unnecessary exposure of acetone which has negative effects on the pigmented tissues, and to protect the morphology of reptile pads and the other anatomic structures formed by adipose tissue.

Impregnation: The dehydrated specimens were immersed in Biodur S10B/S3, 100:1, silicone polymer mixture. Impregnation process was carried out in two different ways to evaluate which one was more convenient for reptile specimens. One of the monitors, iguanas and Mediterranean chameleons were impregnated in room temperature $\left(+20^{\circ} \mathrm{C}\right)$ and the other individual of these species was processed with low-temperature $\left(-25^{\circ} \mathrm{C}\right)$ impregnation. Besides, Jackson's chameleon, central bearded dragon, yellow-bellied puffing snake, and Emerald tree boa snake which we could include only one 

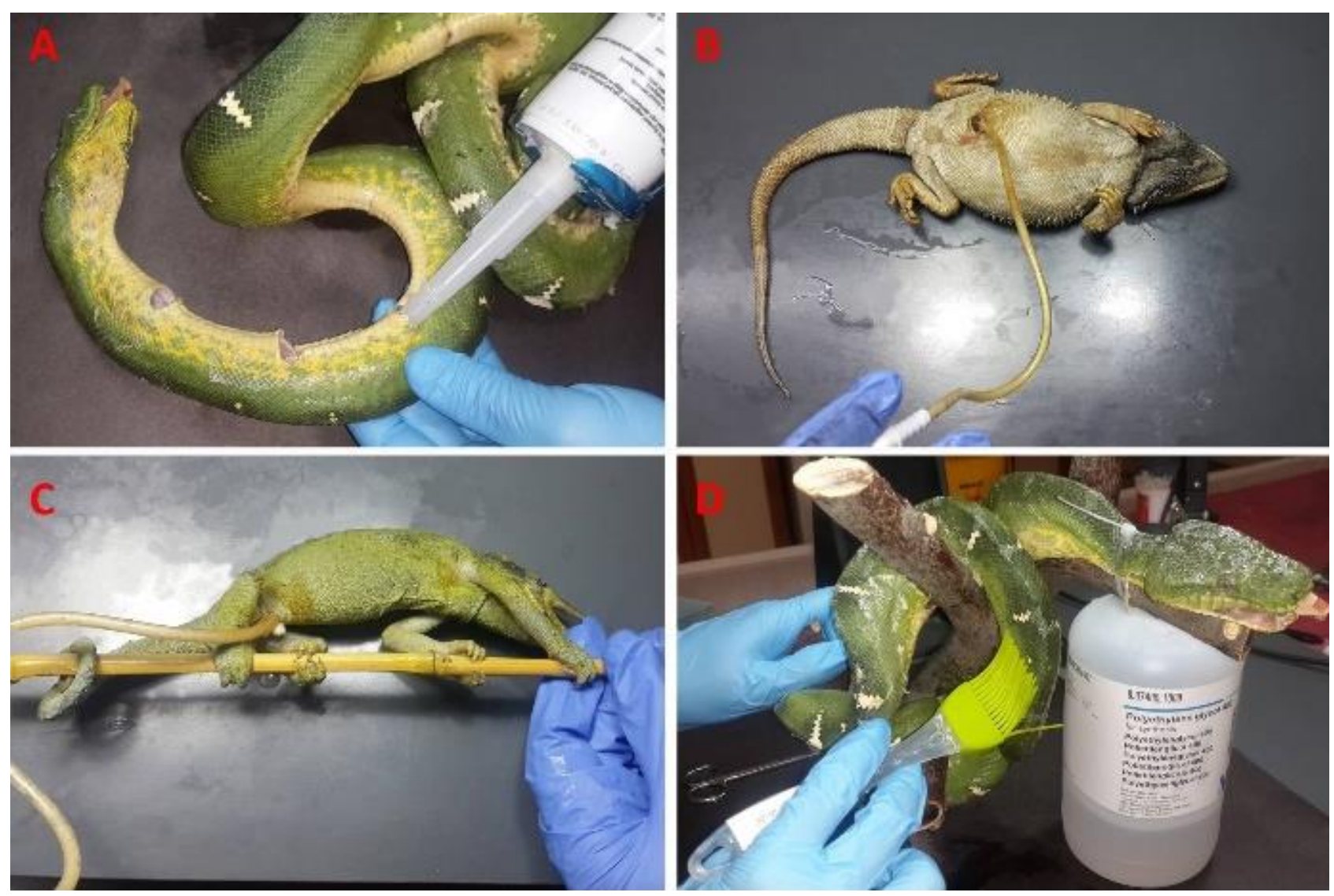

Figure 1. A. Acetone resistant slyl modified polymer injection to Emerald tree boa snake, Polyurethane application to B. Central bearded dragon and C. Jackson's Chameleon, D. Polyethylene glycol 400 application to the Emerald tree boa snake.

Şekil 1. A. Emerald ağaç boa yılanı'na asetona dayanıklı slyl modifiye polimer enjeksiyonu, B. Sakallı ejder'e ve C. Jackson bukalemunu'na poliüretan uygulaması. D. Emerald ağaç boa yılanı'na polietilen glikol 400 uygulaması.
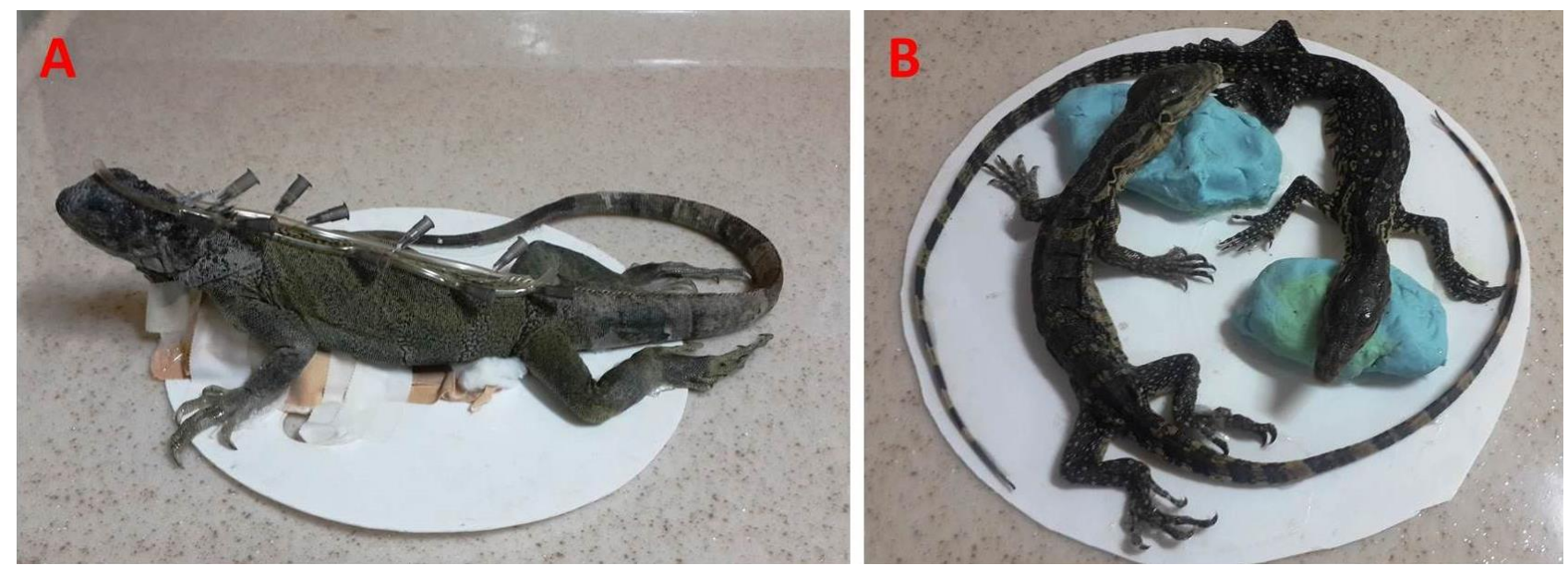

Figure 2. Specimens on which PEG applied and immobilized with various metal, plastic and acrylic piers. A. Green iguana and B. Asian water monitor.

Şekil 2. Metal, plastik ve akrilikten imal edilmiş malzemelerle desteklenmiş ve PEG uygulanmış A. Yeşil iguana ve B. Asya su varanı.

individual to this study, were impregnated only in low temperature. The $\mathrm{S} 10 \mathrm{~B} / \mathrm{S} 3$ mixture had been pre-cooled to $-25^{\circ} \mathrm{C}$ for room and low temperature impregnation either to avoid sudden outgassing of acetone and the unexpected deformation of immersed samples. Furthermore, samples were impregnated separately to determine the exact impregnation period for each species. 
After the vacuum had started, pressure in the chamber was lowered by approximately one third per day. However, the negative pressure in the vacuum chamber was measured with a Bennert's manometer, the impregnation was carried out by observing the surface of silicone where a few acetone bubbles were seen on at every point. The pressure and the bubbling were regulated with a chamber valve to ensure that the impregnation process was being performed properly. Impregnation process was maintained until no acetone bubbles were seen at the highest vacuum.

Gas curing and hardening: Specimens were removed from silicone polymer and kept on a strainer at room temperature for 3 days. This period was quite important for proper silicone oozing. The excess silicone on the surface of the specimens was wiped with a towel regularly. The specimens were positioned for their final appearance and placed in a gas curing chamber containing Biodur S6 in a small glass container at room temperature for 10 days (Figure 3). After gas curing - hardening step, specimens were kept in zip-lock bags for 2 weeks, because the hardening reaction would probably carry on.

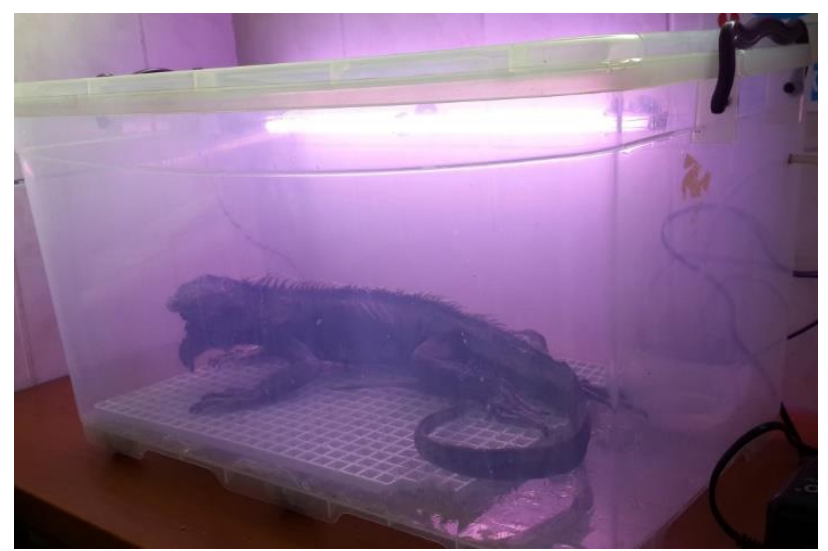

Figure 3. Green iguana in gas curing-hardening stage.

Şekil 3. Gaz kürleme-sertleştirme aşamasındaki yeşil iguana.

The specified parameters such as temperature, processing periods, concentration were monitored and recorded at each step.

\section{Results}

After this modified low and room temperature silicone plastination procedure, plastinates were quite similar to their natural outlook and kept their previous morphologic features. Plastinates were odourless and flexible as well. Acetone resistant polyurethane and silyl modified polymers gave worthwhile results for the protection of hollow parts in their natural morphology. Polyethylene glycol 400 application to the outer surface of the specimens considered as efficient to avoid superficial drying and mould activity. Dehydration parameters for reptile species were indicated at the table (Table 1).
Table 1. Duration of the dehydration step for reptile species. Tablo 1. Dehidrasyon aşamasının türlere göre süresi.

\begin{tabular}{|l|c|c|}
\hline \multicolumn{1}{|c|}{ Species } & $\begin{array}{c}\text { Times of } \\
\text { Acetone Bath at } \\
25^{\circ} \mathrm{C} \\
(\geq 97 \% \text { purity })\end{array}$ & $\begin{array}{c}\text { Duration } \\
\text { (Total } \\
\text { Dehydration } \\
\text { Period - Days })\end{array}$ \\
\hline Mediterranean Chameleon & 2 & 15 \\
\hline Green Iguana & 3 & 22 \\
\hline Asian water monitor & 2 & 13 \\
\hline Jackson's chameleon & 2 & 16 \\
\hline Central bearded dragon & 3 & 20 \\
\hline $\begin{array}{l}\text { Yellow-bellied puffing } \\
\text { snake }\end{array}$ & 3 & 18 \\
\hline Emerald tree boa snake & 3 & 21 \\
\hline
\end{tabular}

Table 2. Duration of room temperature and low temperature impregnation for reptile species.

Tablo 2. Oda sıcaklığında ve düşük sıcaklıkta impregnasyon tekniklerinin türlere göre süresi.

\begin{tabular}{|l|c|c|}
\hline \multicolumn{1}{|c|}{ Species } & $\begin{array}{c}\text { Room } \\
\text { Temperature } \\
\text { Impregnation } \\
\text { (Days) }\end{array}$ & $\begin{array}{c}\text { Low } \\
\text { Temperature } \\
\left(-25^{\circ} \mathrm{C}\right) \\
\text { Impregnation } \\
\text { (Days) }\end{array}$ \\
\hline Mediterranean Chameleon & 6 & 9 \\
\hline Green Iguana & 8 & 11 \\
\hline Asian water monitor & 6 & 8 \\
\hline Jackson's chameleon & - & 9 \\
\hline Central bearded dragon & - & 9 \\
\hline $\begin{array}{l}\text { Yellow-bellied puffing } \\
\text { snake }\end{array}$ & - & 10 \\
\hline Emerald tree boa snake & - & 11 \\
\hline
\end{tabular}

Room temperature impregnation was accomplished in a shorter time for all species - as it was expected - when compared with the one in $-25^{\circ} \mathrm{C}$. The duration of two different impregnation techniques were summarized in the table (Table 2). Gas curing and hardening period was standardized for all species as mentioned above. Even so the final products were elastic and durable as required.

\section{Discussion and Conclusion}

In previous studies, it was mentioned that the hollow organs should be hydrostatically dilated with an air pressure or flushed with water and then fixed in a dilated position to avoid the negative effects of fixation and dehydration $(9,13)$. We observed that rapid hardening polyurethane and silyl modified polymer padding, instead of air pressure, was efficient as well. It dispersed and filled all the gaps in the hollow parts of the specimens. Based on experiences from our previous studies (11) and the current one, we could state that silyl modified polymer padding is convenient to fill the small numerous gaps apart from each other like the body of the snakes with the organs inside. 
The concretion ability of the paddings at $+4^{\circ} \mathrm{C}$ was efficacious and keeping fresh specimens in this temperature during concretion was also functional to reprieve the putrification. Moreover, mechanic extraction of paddings from the same incisions could be quite easy at the end of plastination stages, as they were still elastic. After extraction of paddings, incisions could be widened to demonstrate the internal organs. Therefore, the use of various piers and paddings to provide a better position was very efficacious. Specimens were placed and kept in desirable anatomic position easily during the tough steps of plastination.

It was stated that PEG is not only an effective fixative agent, but also it can prevent the mould growth in the specimens and provide disinfectant activity as well via increasing the penetration ability of formalin solution (1, $6,7,14,19)$. Although we couldn't find a previous study indicating the superficial application of PEG on plastination process, covering with PEG 400 was considered as efficacious not only to prevent the adhesion of excess paddings to the outer surface of the skin, but also to avoid drying and mould activity. For the further studies, we planned to analyse the disinfectant and fixative effects of PEG on plastinates with quantitative methods.

Although the fixation is not essential step for silicone plastination $(9,23)$, our previous experience on mammals (12) and reptiles (11) revealed that the fixated specimens give better results on final products when compared with the non-fixated ones. Wendel et al. injected formalin solution to reptile specimens in their study (35). However, formalin fixation has also negative effects on the colour and volume of the tissues $(23,25,28,29)$, we've made a simple formalin injection and a short term formalin fixation either. Contrary to Wendel et al. (35), our fixation period was quite shorter than the reported parameters in their study. According to the study of Sirinivasan et al. (31), the coefficient of diffusibility for $4 \%$ formalin solution is approximately $0.78 \mathrm{~mm}$. Therefore, the 48 hours of formalin fixation was considered as adequate for the specimens in our study.

However, the dehydration step was carried out at $25^{\circ} \mathrm{C}$, the effects of pure acetone on the skin and the shrinkage of the tissues that Brown et al. (8) had mentioned was a problem for the specimens. Strictly monitoring the acetone concentration helped us to complete dehydration step as short as it could be. Unlike Wendel et al. (35) and Pendovski et al. (25) defatting stage was skipped due to protect the morphology of pads and the other anatomic structures formed by adipose tissue.

In accordance with Sagoo and Adds (29), lowtemperature dehydration and room-temperature impregnation of reptile specimens gave good results. Room-temperature impregnation was shorter than the low- temperature one as it was expected. The shrinkage and colour alterations in plastinates impregnated in room temperature were quite similar to that achieved during low-temperature impregnation. The final colours of the specimens were darker than their natural colour. But, using of pigmented silicone polymer (S10B) was more efficient to obtain closer colours to the natural look of skin and especially internal organs when compared with our previous studies $(3,11)$ which were performed with common S10 impregnation polymer. It is considered that the quantitative measurement of volume and the colour alterations of specimens for each step should be planned for further studies.

To conclude, it was revealed that this modified silicone method can be an alternative for the proper silicone plastination of reptile specimens. In addition, quick hardening, acetone resistant polymers are convenient paddings for the plastination of hollow structures. It is considered that preparation of various reptile plastinates for different reptile practices can be an efficacious method for practical teaching of reptiles.

\section{References}

1. Al Aiyan A, Weigner J, Lübke-Becker A, et al. (2012): Long term study on microbial status in anatomical cadaver fixation using reduced formalin concetration. BJVM, 15, 74.

2. Alworth LC, Hernandez SM, Divers SJ (2011): Laboratory reptile surgery: Principles and techniques. J Am Assoc Lab Anim Sci, 50, 11-26.

3. Bakıcı C, Ekim O, Akgün RO, et al. (2015): Silicone plastination of nerve tissue with different impregnation polymers: Evaluate the effects of pigmentation on the final products. 9th National Veterinary Anatomy Congress. Elazığ. 7-10 September 2015. p 81-82.

4. Bartlett RD (2006): The 25 Best Reptile and Amphibian Pets. Barron's Educational Series Inc. New York.

5. Bickley HC, Walker AN, Jackson RL, et al. (1987): Preservation of pathology specimens by silicone plastination. An innovative adjunct to pathology education. Am J Clin Pathol, 88, 220-223.

6. Bradbury SA, Hoshino K (1978): An improved embalming procedure for long lasting preervation of the cadaver for the anatomical study. Acta Anat Basel, 101, 97-103.

7. Brenner E (2014): Human body preservation- old and new techniques. J Anat, 224, 316-344.

8. Brown MA, Reed RB, Henry RW (2002): Effects of dehydration mediums and temperature on total dehydration time and tissue shrinkage. J Int Soc Plastination, 17, 28-33.

9. de Jong K, Henry RW (2007): Silicone plastination of biological tissue: Cold-temperature technique BiodurTM S10/S15 Technique and Products. J Int Soc Plastination, 22, 2-14.

10. Demirsoy A (1992): Yaşamın Temel Kuralları Omurgalılar / Amniyota, Sürüngenler, Kuşlar ve Memeliler. I. Bask1, Meteksan A.Ş. Ankara. 
11. Ekim O, İnsal B, Bakıcı C, et al. (2014): Yılanlarda soğuk ortam tekniği ile tüm vücut silikon plastinasyonu. Dicle Üniv Vet Fak Derg, 1, 9-22.

12. Ekim O, Tunalı S, Hazıroğlu RM, et al. (2014): Evcil memeli hayvanlarda böbreklerin soğuk ortam tekniği ile silikon plastinasyonu. Vet Hekim Der Derg, 85, 1-11.

13. Henry RW, Janick L, Henry C (1997): Specimen preparation for silicone plastination. J Int Soc Plastination, 12, 13-17.

14. Janczyk P, Weigner J, Luebke-Becker A (2011): A pilot study on ethanol-polyethylene glycol-formalin fixation of farm animal cadavers. Berl Munch Tierarztl Wochenschr, 124, 225-227.

15. Jensen B, Nyengaard JR, Pedersen M, et al. (2010): Anatomy of the python heart. Anat Sci Int, 85, 194-203.

16. Kumro SL, Crocker AV, Powell RL (2013): Injection plastination: A low-tech, inexpensive method for silicone preservation of small vertebrates. J Int Soc Plastination, 25, 12-17.

17. Lewbart GA, Kishimori J, Christian LS (2005): The North Carolina State University College of Veterinary Medicine Turtle Rescue Team: A model for a successful wild-reptile clinic. J Vet Med Educ, 32, 377-81.

18. Licciardi J (2014): Reptiles and amphibians as pets. JAVMA, 245, 629.

19. MacDonald GJ, MacGregor DB (1997): Procedures for embalming cadavers for the dissecting laboratory. Proc Soc Exp Biol Med, 215, 363-365.

20. Marks DL, Chaney EJ, Boppart SA (2008): Plastinated tissue samples as three-dimensional models for optical instrument characterization. Opt Express, 16, 1627216273.

21. McDiarmid RW, Foster MS, Guyer C, et al. (2012): Reptile Biodiversity: Standard Methods for Inventory and Monitoring. University of California Press Ltd, London.

22. Miklosová M, Miklos V (2004): Plastination with silicone method S 10-monitoring and analysis causes of failure. Biomed Papers, 148, 237-238.

23. Oostrom K (1987): Fixation of tissue for plastination: General principles. J Int Soc Plastination, 1, 3-11.

24. Pashaei S (2010): A brief review on the history, methods and applications of plastination. Int J Morphol, 28, 10751079.

25. Pendovski L, Ilieki V, Nikolovski G (2004): Silicone plastination of a malpositioned long-term formalin-fixed green iguana. J Int Soc Plastination, 19, 40-42.
26. Ravi SB, Bhat VM (2011): Plastination: A novel, innovative teaching adjunct in oral pathology. J Oral Maxillofac Pathol, 15, 133-137.

27. Riderer BM (2014): Plastination and its importance in teaching anatomy. Critical points for long-term preservation of human tissue. J Anat, 224, 309-315.

28. Riepertinger A (1988): Fixation of the brain plastination: Special considerations. J Int Soc Plastination, 2, 8-12.

29. Sagoo MG, Adds PJ (2013): Low-temperature dehydration and room-temperature impregnation of brain slices using Biodur $^{T M}$ S10/S3. J Int Soc Plastination, 25, 3-8.

30. Schenk AN, Souza MJ (2014): Major anthropogenic causes for and outcomes of wild animal presentation to a wildlife clinic in east tennessee, USA, 2000-2011. PLoS One, 9, e393517.

31. Sirinivasan M, Sedmak D, Jewell S (2002): Effect of fixatives and tissue processing on the content and integrity of nucleic acids. Am J Pathol, 161, 1961-1971.

32. Sughanty J, Francis DV (2012): Plastination using standart S10 technique - our experience in christian medical college, vellore. J Anat Soc India, 61, 44-47.

33. Walsh SA, Barrett PM, Milner AC (2009): Inner ear anatomy is a proxy for deducing auditory capability and behaviour in reptiles and birds. Proc R Soc B, 276, 13551360.

34. Weiglein AH, Henry RW (1993): Curing (Hardening, polymerization) of the polymer - Biodur ${ }^{T M}$ S10. J Int Soc Plastination, 7, 32-35.

35. Wendel H, Stark R, Plendl J (2008): Plastination of reptiles for veterinary education. $14^{\text {th }}$ International Conference on Plastination. July 20-26, 2008. J Int Soc Plastination, 23, 62-63.

36. Zheng WX, Zhou JN, Yu SB, et al. (2013): Effects of time and temperature of curing on hardness of organs in silicone plastination. Acta Anatomica Sinica, 44, 368-371.

37. Zwart P (1964): Studies on renal pathology in reptiles. Path Vet, 1, 542-556.

Geliş tarihi: 21.01.2016 / Kabul tarihi: 06.10.2016

Address for correspondence:
Assoc. Prof. Dr. Okan Ekim
Ankara University, Faculty of Veterinary Medicine
Department of Anatomy
O6110 Altindag / Ankara - TURKEY
Phone: +905325937295
E-mail: okanekim@yahoo.com

Address for correspondence:

Ankara University, Faculty of Veterinary Medicine

Department of Anatomy

Phone: +905325937295

E-mail:okanekim@yahoo.com 